\title{
Youth Music Production and Consumption in Africa
}

\author{
Producción y consumo musical juvenil en África
}

\author{
Akeem Ayofe Akinwale \\ aakinwale@unilag.edu.ng \\ Department of Employment Relations and Human \\ Resource Management, \\ University of Lagos, Nigeria
}

\begin{abstract}
In view of the need to promote perspectives that move beyond the familiar narratives of social problems among young people, this article examines their contribution to the production and consumption of popular music in Africa. The data used for this article were taken from a systematic review of the relevant literature and insights from theories such as structuration, Afrikology, diffusion of innovation and planned behaviour. These theories were synthesised for a better understanding of the role young people play in the production and consumption of popular music in Africa. The findings revealed that many youths have contributed significantly to the production of popular music in Africa, while some have also encouraged its consumption by developing entrepreneurship in the music industry in Africa. In conclusion, music production has become a viable source of survival for many youths, as well as a reliable means of entertainment for individuals and corporate organisations in Africa. By examining several cases of music production and consumption across Africa, this article establishes a cross-cultural conversation about the visibility and significance of youths in the production and consumption of popular music in Africa. This shows that policymakers and other stakeholders in youth development can encourage youth people to explore entrepreneurial opportunities in the music industry as a catalyst for sustainable development in Africa.
\end{abstract}

KeYwords: Africa; Music Production; Music Consumption; Youth Cultures. 
RESUMEN: En vista de la necesidad de promover perspectivas que van más allá de las narrativas familiares de los problemas sociales entre los jóvenes, este artículo examina su contribución a la producción y el consumo de música popular en África. Los datos utilizados para este artículo se tomaron de una revisión sistemática de la literatura relevante y de las perspectivas de teorías tales como la estructuración, la afrikología, la difusión de la innovación y el comportamiento planificado. Estas teorías fueron sintetizadas para una mejor comprensión del papel que los jóvenes juegan en la producción y el consumo de la música popular en África. Los resultados revelaron que muchos jóvenes han contribuido significativamente a la producción de música popular en África, mientras que otros también han fomentado su consumo mediante el desarrollo de la iniciativa empresarial en la industria de la música en África. En conclusión, la producción musical se ha convertido en una fuente viable de supervivencia para muchos jóvenes, así como un medio confiable de entretenimiento para individuos y organizaciones corporativas en África. Al examinar varios casos de producción y consumo de música en África, este artículo establece una conversación intercultural sobre la visibilidad y la importancia de los jóvenes en la producción y el consumo de música popular en África. Esto muestra que los encargados de formular políticas y otras partes interesadas en el desarrollo de la juventud pueden alentar a los jóvenes a explorar las oportunidades empresariales en la industria de la música como un catalizador para el desarrollo sostenible en África.

Palabras clave: África, producción musical, consumo de música, culturas juveniles.

RESUM: Davant la necessitat de promoure perspectives que van més enllà de les narracions familiars dels problemes socials entre els joves, aquest article examina la seua contribució a la producció $i$ al consum de la música popular a l'Àfrica. Les dades utilitzades per a aquest article es van extreure d'una revisió sistemàtica de la bibliografia pertinent i de les teories com ara l'estructuració, l'africologia, la difusió de la innovació i el comportament planificat. Aquestes teories es van sintetitzar per comprendre millor el paper que juguen els joves en la producció i el consum de la música popular a l’Àfrica. Les troballes van revelar que molts joves han contribuït significativament a la producció de música popular a l'Àfrica, mentre que alguns també han fomen- 
tat el seu consum mitjançant el desenvolupament de l'esperit emprenedor en la indústria de la música a l'Àfrica. En conclusió, la producció musical s'ha convertit en una font viable de supervivència per a molts joves, així com un mitjà segur d'entreteniment per a particulars i organitzacions corporatives a l'Àfrica. En examinar diversos casos de producció i consum de música a l’Àfrica, aquest article estableix una conversa intercultural sobre la visibilitat i la importància dels joves en la producció i el consum de la música popular a l'Àfrica. Això demostra que els responsables polítics i altres actors del desenvolupament juvenil poden animar els joves a explorar oportunitats empresarials en la indústria musical com a catalitzador del desenvolupament sostenible a l’Àfrica.

Paraules clau: Àfrica, producció musical, consum de música, cultures juvenils.

\section{Introduction}

$\mathrm{T}$ The concept of youth has been examined from demographic and socio-cultural perspectives, including chronological age, mental age, adolescence, peer pressure, sexual identity, marital status, courtship, and predisposition to risky behaviour (Barak, 2009). According to Comacchio, "Teenagers are seen to inhabit a world in which established values and their related customs are disintegrating, families are fragmenting, and parents and other elders are disregarded in favor of the peer group" (2006, p. viii). In this context, the growing apprehension about the younger generation has been described as the "youth problem". In her description of youths' behaviour in the post world war eras in Canada, Comacchio noted that young Canadians "actively contributed to reconfiguring the institutions and practices that governed their age group" (2006, p. 1). Young Canadians were frequently expected to defend themselves against the charges of frivolity and delinquency during and after the First and Second World War. However, studies on youth cultures largely ignore the question of youth in Africa, despite the fact that youths constitute about 70 percent of the population in Africa, where average life expectancy is also 55 years (Cohen, 2003; DeJaeghere \& Baxter, 2014; Ramirez, 2005; Sesay, 2014; Taban, 2017). 
At the same time, the large youth population has contributed to high rates of unemployment and poverty in Africa. Regarding the youth population in Africa, some researchers have observed that young people's visibility has been consistently high in different parts of the world (Clarke, Hall, Jefferson, \& Roberts, 2003), although Africa has the largest youth population globally. In their description of youth in Britain, Clarke et al. (2003, p. 9) submitted that:

Youth appeared as an emergent category in post-war Britain. Youth provided the focus for official reports, pieces of legislation, official interventions. It was signified as a social problem by the moral guardians of the society. Above all, youth played an important role as a cornerstone in the construction of understandings, interpretations and quasi-explanations about the period.

While the above description refers to the situation in Britain, the youth question is a global issue, although there is no universal agreement on the definition of youth. Sesay's (2014) analysis of how youth is defined in Africa is relevant here. In South Africa, youths are considered to be between the ages of 14 and 35, whereas in Ghana and Sierra Leone the range is from 15 to 35 years old. In Nigeria the range is between 18 and 35, and in Kenya, between 15 and 30. Similarly, the Economic Community of West African States (ecowas), and the African Union (au) define the youth age range as between 15 and 35 years old.

Unlike the various classifications in African countries, the United Nations (un) defines youth as those in the 15-24 years age bracket. In his evaluation of definitions of youths, Sesay (2014) noted that irrespective of the differences in age ranges, African countries seem to attach a lot of importance to the youth population for the following reasons: (1) youths are perceived as future leaders, (2) they require social, economic and political support to fully realise their potential, (3) they are energetic, ambitious, enthusiastic and creative. In light of the above, this article adopts the South African definition of youths as persons between the ages of 14 and 35, as it is relatively more inclusive.

A close observation of the socio-economic activities among African youths reveals that they are influential in the production and consumption of popular music, which Frith and Horne (1987) described as a generic term for 
different genres of music that appeal to the tastes of a large segment of the population, including folk and blues.

Popular music is usually aimed at the general public and the youth market. Most modern commercial music can be described as popular music. The volumes of music produced or consumed by African youths are innumerable. The nomenclature of popular music varies from one country to another.

As Agawu (2003) observes, the music of Africa has attracted many converts, adherents, and enthusiasts. The vitality of African music can be observed at different locations, including concerts in parks, museums, school playgrounds, and community centres. Other spheres of influence of African music are seen in the performances of celebrity singers, dancers, drummers, guitarists, and bandleaders. The beauty of African music allows for a spontaneous and authentic expression of emotion. Popular music has become an integral part of the social life of Africans at home and those in the diaspora. Consistent with the rationale for youths' involvement in the production and consumption of popular music in Africa, Agawu (2006) opined that little effort is required on the part of Africans to produce reasons for wanting to celebrate the extraordinary range and depth of their music and artistic resources. The veracity of this observation can be derived from the experience of African youths in terms of their motivations to produce and consume popular music. A narrative of the prevailing experience among African youth shows that:

To be young in Africa came to mean being disadvantaged, vulnerable and marginal in the political and economic sense. A long historical process, shaped by authoritarian colonialism, post-colonial state failure and a generally problematic engagement with material modernity has yielded the conditions of crisis and upheaval under which youths in Africa are growing up. (Abbink, 2005, p. 7)

This picture of African youth cannot be managed successfully without an understanding of their role in finding their own answers to the problems they face. The agency perspective provides a basis for an understanding of the versatility and resilience of African youth.

Research on youths' engagement with social networking sites and how these social media affect the ways youths interact with one another in the USA shows that they use sites such as MySpace and Facebook to gather information, 
socialise with their peers, and make sense of and help build the culture around them (Boyd, 2007). This implies that participation in social network sites can stimulate youths' interest in the production or consumption of popular music. Some researchers have observed that innovations in technology shape how youths interact with each other at different locations such as schools and homes (Goldman, Booker, \& McDermott, 2008). The American experience shows that many youths have learned to participate in civic and democratic practices such as producing and consuming popular music by using information and communication technology, which offers opportunities for youths to have an influence in their communities.

In light of the above, this article examines the role of youths in the production and consumption of popular music in Africa from perspectives that move beyond the familiar narratives of social problems among young people. The specific research questions that informed the subject matter of this article are as follows:

1. From where do youths in various parts of Africa derive the inspiration to produce or consume popular music?

2. Of what value is the production of popular music in various parts of Africa?

3. How accepted are different genres of popular music in various parts of Africa?

4. How does emerging entrepreneurship in the music industry encourage the consumption of popular music in Africa?

These questions were examined through a systematic review of the relevant literature and a comparative analysis of several cases of music production and consumption across Africa. Aside from the abstract, introduction and conclusion, the main body of the article is structured in the following sections: methods of data collection and analysis, the theories of youth music production in Africa, the concept of popular music, the origin and development of popular music, inspirations for the production of popular music in Africa, the values attached to the production of popular music in Africa, the level of acceptance of popular music in Africa, and the influence of entrepreneurship in the music industry on consumption of youth music in Africa. 


\section{Methods of data collection and analysis}

The data used for this article were gathered from a systematic review of the relevant literature, with a focus on the following issues: the origin and development of popular music, the values attached to youth music production in Africa, the level of acceptance of popular music in Africa, and the linkages between emerging entrepreneurship in the music industry and consumption of music in Africa. The literature review was carried out to expand the frontiers of knowledge on youth participation in the production and consumption of popular music in Africa.

Relevant literature was identified from academic databases such as Google Scholar, JSTOR, EBSCOHost, and Science Direct. All the relevant literature extracted from these databases was subjected to content analysis to reflect the research questions stipulated above. Case studies of music production and consumption across Africa were also selected for illustrative purposes. These case studies were selected on the basis of relevance, geographical spread, and availability of reliable data.

The article's subject matter drew on an integration of the main ideas in the theories of structuration, Afrikology, diffusion of innovation and planned behaviour, which provided a suitable framework to advance understanding of the rationale behind youth participation in the production and consumption of popular music in Africa.

The theory of structuration was used to analyse the young people's strengths, while the theory of Afrikology helped to explain the importance of oral tradition in Africa. A synthesis of the main ideas in the theories of structuration and Afrikology implies that, through the creative use of talents in the production and consumption of music, young people's power can be harnessed to develop the oral tradition in Africa.

Additionally, considering the influence of globalisation on the structures and processes of decision making across the world, the main ideas from the theory of diffusion of innovation and planned behaviour were included in the theoretical framework to enhance the young people's capacity in their conscious efforts to make a difference through their musical talents. A des- 
cription of the main insights from each of the aforementioned theories is presented in the next section.

\section{Theories of youth music production in Africa}

The rationale behind youths' participation in the production and consumption of popular music in Africa can be observed through the lens of the following theories: structuration theory, diffusion of innovation theory, Afrikology and the theory of planned behaviour. Structuration theory is based on Giddens' (1984) analysis of the social structure in England, while innovation theory derives from an observation of the significantly positive outcomes following the introduction of hybrid corns by many farmers in Iowa, USA (Rogers, 2010). The co-existence of traditional and modern lyrics in the production and consumption of popular music in Africa can be examined from the main ideas in the theory of Afrikology, which Nabudere (2011) developed in East Africa.

In addition, the need for conscious efforts to sustain the production and consumption of popular music in Africa is the main reason for including Ajzen's (1991) theory of planned behaviour. This theory explains why individuals may make certain decisions, such as taking part in producing or consuming popular music.

Giddens (1984) identified the essence of structuration theory as an understanding of the power of human agents in the social construction of reality. The theory focuses on the relationship between agency and structure. This implies that all social actions occur within a structure, and all structures require social actions. Structuration theory offers an appropriate frame to analyse the role of youth in the production and consumption of popular music in Africa. In this case, youth agency implies young people's power to make a significant difference in the African music industry.

However, existing studies on youth agency largely focus on the cultural contexts of technologically advanced economies, while academic research on youth experiences in African countries is still scant. The theory of Afrikology is adopted to fill this gap and provide a better understanding of the role of young people in the production and consumption of music in Africa. 
The main ideas in the theory of Afrikology reinforce the use of oral messages as a valid source of knowledge. This clearly shows how African youths can contribute to the development of knowledge through the production of popular music. In his interpretation of the theory of Afrikology, Wanda (2013, p. 2) posited that:

It recognises all sources of knowledge as valid within their historical, cultural or social contexts and seeks to engage them into a dialogue that can lead to better knowledge for all. It recognises peoples' traditions as a fundamental pillar in the creation of such cross-cultural understandings in which the Africans can stand out as having been the fore-bearers of much of what is called Greek or European heritage.

Nabudere (2011) developed the theory of Afrikology as a refinement of the political philosophy of Pan-Africanism. It is important to note that the debates that led to the development of the theory of Afrikology were based on the quests for political independence and socio-economic development in Africa. Such debates are consistent with the themes of pan-Africanism and African renaissance.

Starting from the Afrocentric consciousness that led to the formation of the Pan African Movement in the early twentieth century and the Manchester Conference in 1945, some young people were actively involved in the African liberation struggles against colonialism. Indeed, virtually all the twelve African participants at the Manchester Conference could be defined as youths, including Kwame Nkrumah who was appointed Secretary General at the Conference, Nnamdi Azikiwe of Nigeria, and Wallace Johnson of Sierra Leone (Sesay, 2014). Kwame Nkrumah later returned to Ghana to found the Convention Peoples Party, which led Ghana to political independence on March 6, 1957.

Other territories such as Nigeria, Sierra Leone and Kenya gained political independence in 1960, 1961 and 1964, respectively, under the leadership of young men. Similarly, in Francophone Africa, Leopold Sedar Senghor of Senegal, Sheku Toure of Guinea and Felix Houphouet Boigny of Cote d'Ivoire successfully achieved political independence from France, starting with Guinea in 1958, while 16 other Francophone territories gained their independence in 1960. 
In East Africa, Jomo Kenyatta, Tom Mboya, and Julius Nyerere were at the forefront of the liberation struggles that led to the independence of their respective countries. Thousands of youths also paid with their lives during the colonial and anti-apartheid struggles in South Africa. However, the theory of Afrikology is not a suitable frame in which to develop an understanding of the emerging changes in Africa. In this case, the diffusion of innovation theory is used to illustrate the external factors affecting the level of youth participation in the production and consumption of music across Africa.

Rogers (2010) developed the diffusion of innovations theory to explain the structure and processes involved in the adoption of new ideas in the USA. Diffusion of innovation theory is based on the fact that:

Getting a new idea adopted, even when it has obvious advantages, is often very difficult. Many innovations require a lengthy period, often of many years, from the time they become available to the time they are widely adopted. Therefore, a common problem for many individuals and organizations is how to speed up the rate of diffusion of an innovation. (Rogers, 2010, p. 1)

Rogers' (2010, p. 5) definition of diffusion as "the process by which an innovation is communicated through certain channels over time among the members of a social system" implies that the main elements in this process are innovation or new ideas, communication channels, time, and the social system. The adoption of an innovation requires certain processes such as awareness and interest. Awareness of innovations depends on factors such as mass communication, observation of nature, work environment, social interaction and personal contacts. In addition, interest in adopting an innovation depends on existing attitudes among the potential adopters (Valkonen, 1970).

The spread of innovations from Europe and North America to Africa has meant that some African youths have successfully created new genres of popular music in Africa, thereby contributing to the growth and development of the innovations explored in this paper. Some instances of innovations adopted in the African music industry can be examined from entrepreneurial perspectives. In her study of the factors influencing youths' attitude to entrepreneurship, Dioneo-Adetayo (2006) discovered the importance of learning and experience as major determinants of youths' interest in entrepreneurship. 
She also attributed their interest in entrepreneurship to relevant external factors such as infrastructure, funding, and information and communication technology (ICT). In this vein, Suleiman (2015) noted that inability by governments to promote entrepreneurship has discouraged many youths with bright entrepreneurial ideas.

The theory of planned behaviour can also enhance understanding of youths' ability to innovate in the production and consumption of popular music in Africa. Ajzen (1991) developed this theory to demonstrate how human behaviour is guided by different considerations such as behavioural beliefs, normative beliefs, and control beliefs.

Behavioural beliefs refer to an individual's beliefs about the likely outcomes of a given behaviour. Normative beliefs allude to an individual's perception of the expectations of others in a given situation. Control beliefs refer to the availability of factors that may facilitate or impede the performance of a given behaviour. Control beliefs would, in this case, represent the enabling environment for youth music production in Africa. With a more favourable attitude and subjective norm, and a greater level of the perceived control, youths' intention to embark on the production or consumption of popular music in Africa would be strengthened.

Moreover, given a sufficient degree of real control over the processes of production or consumption of popular music, young people would actively participate in these activities when the opportunity arises. The theory of planned behaviour suggests that youths can exhibit a favourable attitude towards the production or consumption of popular music, depending on their subjective norms and the perceptions of what the people relevant to them think about their decision to become a producer or consumer of popular music, and more specifically, the perceived ease or difficulty of doing so.

This theory essentially holds that youth music production and consumption is a product of planned and intentional behaviour, which depends on a favourable attitude towards popular music, and the perceived ease of becoming a popular musician or consumer of popular music, as the case may be. Malebana (2014) used the theory of planned behaviour to examine entrepreneurship intention of students in a South African university and reported that most of the students intended to start a business in the future. Considering the fact 
that an intention to make certain decisions could be based on beliefs and perceptions (Ajzen, 2002), African youths who perceive popular music as favourable are therefore more likely to engage in the production or consumption of popular music.

\section{The concept of popular music}

In the course of his observation of the development of music in America, Hamm (1995) recognised the advent of popular music from two distinct bodies of music. The first category comprises "composed songs, notated and disseminated in the form of sheet music, aimed at a wide audience of amateur musicmakers" (Hamm, 1995, p. 118), while the second category contains "oral-tradition music stemming from various non-literate sub-cultures in the United States" (ibid, p. 118).

Examples from the second category are children's ballads and songs; most Afro-America music; white and black American dance music; and the music of other ethnic and racial minorities. The first category of music is usually referred to as the popular song, while the second category is known as folk music.

At the beginning of the twentieth century, dissemination of the first category of music grew with the advent of the phonograph disc, and in the 1920s and 30s through radio and sound film. This process of dissemination via the phonograph disc and radio did not begin until the 1920s in the case of the second category. According to Hamm, "Distinctions between the two categories of popular music eventually became matters of musical style and the socio-economic status of their performers and audiences" (ibid, p. 119).

This description of the dissemination of popular music shows how contemporary information and communication technologies such as radio, phonograph disc, and sound films transformed popular songs and folk music into popular music through the need to produce music for mass audiences or public performance, for different reasons.

In Towards an Aesthetic of Popular Music (1987), Frith argued that popular music has four social functions that account for its value and popu- 
larity in society: (1) it provides answers to questions about identities and our place in society; (2) it offers us a way to manage the relationship between public and private emotional lives; (3) it gives us a sense of time and shapes popular memory; and (4) it is something that we can own .

The study of popular music has attracted considerable attention among musicologists and other professionals in different countries. One international organisation dedicated to the scholarly study of popular music is the International Association for the Study of Popular Music (IASPM), which was established in 1981 (Frith, 1996) and since 2002 has been based at the University of Liverpool's Institute of Popular Music. Membership of the IASPM had spread to 30 countries by 1988 .

\section{The origin and development of popular music}

Music can flow from many voices in any culture, and as such it is irrational to claim popular music originated in only one place. The African or non-African origin of popular music therefore deserves attention. Anthropologists have traced the origin of music from the evolution of mimesis, that is, imitation or mimicry, in which, according to Massey (2002) "vocalizations, facial expressions, eye movements, body postures, and manual signs were used to communicate". This process produced the mimetic culture, which gave humans a powerful adaptive tool that enabled them to migrate from Africa to a wider variety of habitats in Europe and Asia.

As Green (2016) has reported, ethnomusicologists and music anthropologists have observed societies in which music-making is a habitual activity in the lives of practically every member of the community from a very early age. This is illustrated by Messenger's (1958, p. 20) account of the experience of music production among the Anang and Ibibo people of Nigeria:

We were constantly amazed at the musical abilities displayed by these people, especially by the children who, before the age of five, can sing hundreds of songs, both individually and in choral groups and, in addition, are able to play several percussion instruments and have learned dozens of intricate dance movements calling for incredible muscular control. 
This observation confirms that music is a major part of youth identity in Africa. It has been produced and consumed for purposes as varied as play, work, celebrations, rituals and worship, as well as to transmit history, moral lessons and communal values in many traditional societies.

In their description of the essence of music, Fleming and Falola $(2012, \mathrm{p} .1)$ noted that "music, song, dance and performance can possess multiple meanings and purposes in Africa". In essence, African popular music has developed out of the public's interest in entertainment, although to a large extent it reflects issues relating to political situations and socio-economic conditions on the continent.

Wulstan (1985) described sixteenth-century Tudor England where musicmaking was a normal part of everyday life. Hired musicians played and sang for the rich, while the minstrels created music for the poor. Ehrlich (1985) describes the bustle of music-making and music teaching in eighteenth- and nineteenth-century middle- and upper-class homes. In his analysis of the spread of music in England, Russell (1997) observed that music is a vital and indispensable element of English life. Below is another account of the origin and development of popular culture focused on the European experience:

The nineteenth-century mapping of musical taste in Europe was bound up with shifting identities within the middle class. From the 1830s a high-status, affluent "popular" classical music public came to dominate musical institutions, and to merge with upper-class audiences, to adopt "art" musical values. (Frith, 1996, p. 28)

In her work on the origin of popular music, Green (2016) noted that popular music first gained support from educators during the late 1960s when jazz first entered formal music education in the USA, from where it spread to other countries. Porter's (2002) study shows how some African American musicians have celebrated jazz as a symbol of black people's accomplishments. Jazz has also been used to celebrate the African-American life and culture. Many young Africans have developed an interest in jazz, as well as other genres of popular music. 


\section{Inspirations for the production of popular music in Africa}

The production of popular music is an organised activity involving a collective action or joint effort by several people (Becker, 1989; Martin, 2006). As Longhurst (2007) describes, popular music requires the involvement of different categories of people or institutions because it does not occur spontaneously; it is the result of production processes that involves various institutions. In some cases, music production may be relatively simple, while in others, it can be exceedingly complex.

Thus, a recording will be the outcome of a complex set of procedures involving different people and social processes, including musicians, recording engineers, record producers, playing instruments, interaction in a recording studio, mixing tapes, the manufacture of $\operatorname{CDS}$ in a factory and so on. Such cultural objects are not only produced, they are also consumed, or read, by an audience or audiences, and it is necessary to study the processes that occur here. Most cultural productions take place within an economic context where the profit motive is paramount. It is important to consider precisely how production takes place. Therefore, it will be necessary to consider whether people collaborate in the process of production. (Longhurst, 2007, p. 21)

The importance of different categories of music can be considered in this regard. A close observation of the sources of inspirations for the production of popular music shows that many musicians have acquired their knowledge through formal or informal methods of learning. Many youths in Africa acquire their knowledge of popular music through informal methods of learning such as observations and imitations of certain musicians and encouragement from relatives or peers.

In light of the above, it has been argued that both formal and informal methods of music education are not mutually exclusive, as many musicians from formal music education backgrounds engage in some informal learning practices, such as teaching themselves to play a popular song, while others whose education has been largely informal have had some formal music education (Green, 2016).

There is no question that knowledge of popular music can be acquired through formal education; however, little is known about the impact of formal 
music education on the rates of youth participation in the production and consumption of popular music in Africa.

The realities on the ground in sub-Saharan Africa also point to the fact that some young people have been inspired to produce popular music as a result of widespread socio-economic problems in Africa. This school of thought is consistent with Abbink's (2005) observation that the coming of age of a new, educated and aspiring generation of young people, frustrated by mass unemployment, political instability and corruption, has increased the rate of youth activism in Africa.

Similarly, Sesay (2014) noted that African youths have historically played diverse key roles in the transformation of their societies, from the struggle for political freedom to the pursuit of economic sustainability. Consistent with this observation, Dioneo-Adetayo (2006) found evidence of youth involvement in entrepreneurial activities in the music industry in the urban and rural areas of Africa.

TheAfrican Union has introduced policies to inspire African youths towards sustainable development. These policies include the 2009-2018 Ten-Year AU Plan of Action for Youth Empowerment and Development, the AU Youth Volunteer Corps Programme and African Youth Day (Taban, 2017). In recognition of the role young people play in African socio-economic development, the AU launched the International Year of the Youth on 1 November 2010.

\section{ICT use in the production and consumption of popular music in} Africa

A close observation of the forces of production in the African music industry shows the significance of the spread of ICT such as computers, radio, television, mobile phones, compact discs (CD) and the social media (Goldman, Booker, \& McDermott, 2008).

Thompson (1995) described the mass media as an institution with the power to provide other institutions with the means to make their power felt in society. The ability to spread messages to a multitude of people over large territories is what gives the media its power. The role of radio and television in national development has been observed in Africa. 
Social media platforms such as Facebook, You Tube, Google, WhatsApp, and Instagram have become very popular among African youths and have contributed significantly to the spread of popular music in the continent. In fact, due to the internet revolution, African governments have been unable to prevent the youths from voicing their opinions (Abbink, 2005).

Following an ethnographic approach in their study of Ghanaians in London, Burrell and Anderson (2008) reported how their use of a wide range of ICTS (camcorders, digital cameras, mobile phones etc.) was shaped by their personal aspirations and social landscapes. They uncovered two trajectories in ICT use among their informants. One trajectory reflects the "transnational practices of cultural continuity and 'looking homeward", as shown by the incorporation of ICTs like camcorders into social events of the Ghanaian community in London. The second trajectory was revealed in their recourse to the internet in their exploration of the world to fulfil their aspirations, searching widely for opportunities, contacts, information, and new ideas, including popular music. The use of the internet for different purposes including production and consumption of popular music showed that ICTS were relevant to Ghanaians in the diaspora in ways other than maintaining contact with their home country.

In addition, Mercer's (2005) survey of cyber cafes and telecentres in Tanzania revealed how the internet has transformed Tanzanians into knowledgeand market-seeking productive citizens, thus confirming the existence of Tanzania's ICT elites. As she notes, "For Internet cafe users and non-users, the Internet has become a marker of modernity, a way for people and places to indicate their relative level of development", (2005) finding that internet use in Tanzania is driven by the need for leisure and relevant information on popular music. Mercer (2005) however noted that many Tanzanians are excluded from the information society as a result of the symptoms of poverty.

\section{The values attached to producing music in Africa}

Bennett (2000) examined the various ways in which sociologists have theorised popular music, affirming that youths produce and consume music "in ways that both inform their sense of self and also serve to construct the social world in which their identities operate". Some cases of production and consumption of popular music across Africa can be examined in this context. 


\section{The Values of Popular Music in South Africa}

Evidence shows that popular music was instrumental in the struggle against South Africa's apartheid regime. Ballantine's (1991) study of music and emancipation through the social role of black jazz in South Africa demonstrates how popular music enhanced the growth and development of the African National Congress (ANC), a leading political party in South Africa.

Of particular interest here was the assertion that there was intrinsically a value in jazz bands or vaudeville troupes incorporating musical and other materials that were African; and this in turn was part of a broad groundswell of militant protest in the early 1940s, expressed ideologically in the philosophy of New Africanism, and politically in the formation of the ANC Youth League (Ballantine, 1991, 129).

The use of music as a counterforce against apartheid led to Miriam Makeba's exile from her home and family in South Africa. She spoke on the horrors of apartheid at the United Nations Decolonization Committee in 1963 (Miller \& Makeba, 2000), and at the United Nations Committee on Apartheid in 1964. Makeba used popular music to spread the narratives of the historical experience of South Africans. She worked closely with musicians in Africa and Europe, particularly from South Africa, Madagascar, Congo and France.

In his analysis of the value of popular music in South Africa, Martin examined the role of urban music in the social construction of identities in Cape Town, showing how "music, festivals, cuisines, and indeed languages are used as emblems of identity and signs of difference" (2013, pp. 7-9). All the musicians he interviewed attributed the uniqueness of Cape Town's music to its historical mix of European and African lyrics and the beauty of the ghoema beat. Cape Town was the first outpost of creolisation in South Africa and the growth of popular music in Cape Town played a decisive role in shaping the development of popular music across South Africa.

The spread of popular music was made possible via Radio Bantu, founded in 1962, and South African Television (SATV), which was established in 1976. The South African Broadcasting Corporation (SABC) and other media have also fanned its growth across South Africa. The 1980s marked a watershed in the development of popular music in South Africa with the emergence of the 
Music Action for People's Power (MAPP) in Cape Town in 1986 and the South African Musicians' Alliance (SAMA) in 1987.

I share the belief of many people that music and involvement in musicmaking are of unique value to humanity. Having been a piano teacher, school music teacher and music education lecturer and writer within various formal settings all my life, I am also in no doubt that formal music education offers wonderful experiences and opportunities to millions of children and adults worldwide. (Green, 2016, p. 8)

A description of the role of music and dance among the Batwana people of South Africa is relevant here, both of which have been used as catalysts for socio-economic development among this community. For instance, one group of musicians, the Ikageng-Bill Cosby Cultural Group, uses the production and consumption of popular music as an opportunity for rehabilitation of the underprivileged such as orphans and street children (Onyeji, 2009). Virtually all the members of this group are poor and they have derived significant socio-economic benefits from music production.

\section{The Values of Popular Music in North Africa}

The spread of popular music has enhanced the co-existence of some local and global cultural practices in North Africa. The death of Cheb Hasni, Algeria's most renowned Rai musician, marked the demise of a genre of popular music in North Africa (Langlois, 1996). He was assassinated on 29 September 1994, becoming one of the many public figures killed as a result of the violence following the annulment of elections in Algeria in 1991. Rai music constructs its own distinct trajectories linking local and global, 'East' and 'West', and, in this way, constitutes a distinct problem for Algerians, and indeed other North Africans (Langlois, 1996). Rai, a popular music originating in urban western Algeria, has changed considerably since its transition from the wedding parties and night-clubs of Oran to open-air concerts and MTV.

\section{The Values of Popular Music in East Africa}

Popular musicians in Kenya have transmitted important messages largely focussing on issues of unemployment, inequality, corruption, disease, housing 
conditions, and the experience of life on the edge. Ogone (2014) reports that Kenya's popular musicians use a range of languages, including Sheng, Kiswahili and English, to address a variety of themes. Musicians from relatively low-income backgrounds have dominated the popular urban musical scene in Nairobi. For these musicians, music provides an avenue to express their identity in a city that has little space for the underprivileged classes.

This situation reflects young people's creativity in the use of popular music as a medium of expression, thereby corroborating Comacchio's observation that during this stage of development young people "first become aware of their place in the arena of history, learn of their larger society and its expectations of them, and begin to question established institutions and the conventions of their elders" (2006, p.5). Comacchio also echoes Marcel Denesi's contention that keeping "young people in a state of enforced dependency is largely responsible for the "youth problem"' (ibid, p.12), which has attracted considerable global attention.

\section{The Values of Popular Music in West Africa}

The new generation of political actors that emerged from the student union movement in support of democracy prompted the evolution of Zouglou music in Cote d'Ivoire in the early 1990s (Schumann, 2013). Zouglou music has attracted many young people from the quartiers populaires of Abidjan. Surprisingly, the students who invented the genre of zouglou music did not pursue a career in music.

Unlike the case of Zouglou music among the youths in Cote d'Ivoire, the pursuit of a career in music has been observed among the youths in Ghana, through the Achimota School of Music. The Achimota School, founded in 1925 as the Prince of Wales College, is now an important site for the production and consumption of music in Ghana (Agawu, 2003). One of the leading centres in West Africa for the study and production of music, the school's logo is a segment of a piano keyboard whose black and white keys symbolise harmony between Africans and Europeans.

Many prominent Ghanaian musicians have been associated with the Achimota. One was Philip Gbeho, the composer of Ghana's national anthem 
and an influential teacher of traditional and European music. Another prominent Ghanaian musician was Dr. Ephraim Amu (199 - 1995), a self-conscious African by virtue of his dress, lifestyles and use of language. Both Philip Gbeho and Dr. Ephraim Amu taught music at Achimota for several years.

A biennial inter-house singing competition provided an opportunity for students to come together and train in choirs, and in some cases, to compose new music or arrange an existing piece for immediate performance. The school's music curriculum prepared students for London Board of Education ordinary and advanced level certificate examinations. The Associated Board of the Royal Schools of Music also sent an examiner each year from the United Kingdom to various African countries such as Sierra Leone, Ghana, Nigeria, and South Africa to examine students in practical subjects (Agawu, 2003).

The other prominent avenues for creative musical expression at Achimota include traditional music and the Pop Chain Competition, which brought together bands from various schools to perform a variety of popular music. Achimota School of Music holds an annual Founder's Day Celebration in which various traditional chants and ritual dances are performed, providing an opportunity for students to enact African traditions by singing African songs, beating African drums, and dancing African dances.

Despite the abovementioned cases of music production and consumption in Cote d'Ivoire and Ghana, no description of the values of popular music in West Africa would be complete without reference to Nigeria and Mali. Nigeria is the most populous country in Africa, making it a major site for the production and consumption of popular music on the continent. This is evidenced by several generations of many prominent musicians in Nigeria, including Ayinla Omo Wura, Dauda Epo Akara, Fela Anikulapo Kuti, King Sunny Ade, Onyeka Onwenu, Sunny Okosun, Ebenezer Obey, Sir Shina Peters, Sikiru Ayinde Barrister, Kollington, Queen Salawa Abeni, Wasiu Ayinde, Abass Obsesere, Malaika, Pasuma, Femi Anikulapo Kuti, Seun Anikulapo Kuti, Lara George, and many others too numerous to mention.

The case of African China is another example of the value of popular music in Nigeria. African China is the nickname of Chinagorom Onuoha, a popular Nigerian musician whose music - galala - reflects issues such as marginalisation of the underclass, critiques of the social structures that produce 
this marginalisation, and the search for improved living conditions among the members of the underclass (Okuyade, 2011). Galala music is a fusion of reggae and afro beat. Its lyrics are rendered mainly in Nigerian Pidgin. Several cases of code-mixing of English and Nigerian languages, including Nigerian Pidgin, have been observed in galala music. The main messages in galala music depict the crisis in Ajegunle - a poor neighbourhood in Lagos - as a metaphorical extension of the problems ravaging Nigeria in particular and Africa in general.

Mande music is included in this analysis of the values of popular music in West Africa due to its long history and significance in West Africa and beyond. The Mande are also known as Maninka in Mali and Guinea, and Mandinka in Senegal, The Gambia, and Guinea-Bissau. The Maninka and Mandinka music culture encompasses a range of musical spheres such as hunters' music and the music played on the bala (xylophone), koni (lute), and kora (harp), and is associated with rulers, warriors, traders and other patrons. Other Mande music spheres include those related to activities such as agriculture and recreation and modern music, known as orchestra.

Charry (2000) examined Mande music with a focus on the hunters' music of the jelis or griots, jembe and other drumming and guitar-based modern music. The great tradition of the jelis' music and its practitioners have spread throughout the world under the patronage of multinational recording companies, African expatriates in Europe and North America and lovers of African music across the world. On the spread of the Mande music, Charry writes that:

Mande musicians have responded to opportunities to perform abroad, just as their forebears have done in their widening zones of influence within Africa. They have accordingly shaped their music for foreign audiences, and it continues to move in disparate directions (Charry, 2000, p. 9)

A significant part of Mande music, guitar-based music, emerged in Guinea in the 1920s. It is rooted in European and Latin American popular dance music, and it eventually drew heavily from other indigenous traditions. Due to the development of Mande music there are now highly trained musicians who are paid for their music production. This situation is replicated in many 
African countries where musicians have received substantial rewards for their musical skills.

\section{The level of acceptance of popular music in Africa}

The degree of acceptance of popular music is relatively high in Africa, where many youths have deployed music not only to channels feelings of dissatisfaction or rebellion, but more broadly to negotiate their position in relation to the elites who exercise authority over them. A clear indication of the high level of acceptance of popular music in Africa is the emergence of the street band movement, which arose in Cape Town in the 2000s to promote underprivileged youths' participation in the production and consumption of music in South Africa.

Other indications of the acceptance of popular music in Africa include its presence at political rallies, wedding parties, motor parks, and so on. As Martin (2013, p. 35) observes:

There is hardly a political meeting, a demonstration, and nowadays, a political clip that does not include music. Political movements and politicians use music as campaign hymns that identify them along with colours, portraits, or mottoes. They can recycle existing songs or commission new ones.

Consistent with this situation is the recognition of African female musicians' talents as singers, instrumentalists and composers. For instance, Cheb Hasni Nyambura of Kenya is a model responsible entrepreneur in the African music industry. Similar successful entrepreneurs in the music industries of other African countries include Christy Essien-Igbokwe and Onyeka Onwenu of Nigeria, Miriam Makeba of South Africa, Angelique Kidjo of the Republic of Benin and Anne-Marie Nzie of Cameroon. These women are among the most prominent female musicians in Africa.

\section{Entrepreneurship and consumption of popular music in Africa}

There are evident linkages between entrepreneurship in the music industry and consumption of music, as noted by Agawu (2003, p. xi): 
The music of Africa continues to draw converts, adherents, and enthusiasts. These and many more activities signal African music's continuing vitality at home and abroad. What is the secret of African music? Some say that it is communal and inviting, drawing in a range of consumers young and old, skilled and unskilled. It allows for the spontaneous and authentic expression of emotion.

The most basic aspect of the musical career is enthusiasm or self-promotion, which is a common feature among aspiring musicians (Weber, 2004). An aspiring musician may identify an unexploited avenue of composition, performance, or production, and find ways to tap into it. An aspiring musician also requires some skills and the ability to identify and seize promising opportunities. Moreover, while the ability to perform or compose new music is necessary, on its own it is not sufficient for a successful career in music. Other requirements for success include the ability to find patrons and attract a public, lead other musicians, and, indeed, organise the production of new music or albums.

We must start taking musicians seriously as business people and as social forces. That involves studying how they acted as entrepreneurs and how they took advantages of opportunities before them. This point applies across the board among the great musicians. (Weber, 2004, p. 3)

A huge proportion of the global population listens to music, many following it on the radio or television, and others through social media. Green (2016) noted that the expansion of the music industry and mass media into major international concerns, together with the internet, have made music more accessible, widespread and sometimes unavoidable to the listener. Most people's involvement with music is as consumers and fans. Green (2016) states that popular music, including folk music and blues, accounts for over 90 percent of the global sales of music recordings, with classical music and jazz making up less than five percent.

Kuratko, Morris and Covin (2011):

note that the nature of entrepreneurship can be captured in seven perspectives, as follows: (i) creating wealth, which involves assuming the risks associated with production in exchange for profit; (ii) creating enterprise, which entails setting up a new business venture where none previously existed; (iii) creating innovation, which aims to combine resources in a unique way, thus 
making existing methods or products obsolete; (iv) creating change, which involves adjusting, adapting and modifying personal attitudes, approaches and skills to grasp opportunities that arise in the environment; (v) creating jobs, which refers to the employment, management and development of the factors of production, including the work force; (vi) creating value, which entails providing value to customers by exploring unexploited opportunities, and (vii) creating growth, defined as a strong, positive orientation towards growth in sales, income, assets and employment.

These seven dimensions of entrepreneurship can be applied to the music industry in Africa to explain how some youths have accumulated wealth from selling and marketing their music. The experience of some prominent musicians in the 14-35 years age bracket in Nigeria and other parts of Africa can be examined in this context. In Nigeria, the list of such musicians includes 2Face, Wizkid, Davido, Daddy Yoo, Orezi, and Tiwa Savage, Simisola, Lara George, among others. These musicians attained fame and enormous wealth within a few years of their debuts in the Nigerian entertainment industry, showing that the production of popular music has become a lucrative business in Africa.

\section{Conclusion}

This article has demonstrated that producing popular music is now a viable means of survival for many young people in sub-Saharan Africa, as well as an established form of entertainment for individuals and corporate organisations across the continent. Most popular musicians in Africa acquired their knowledge of music through informal learning, and are inspired by the prevailing socio-economic situations in Africa. This suggests that some important lessons from the informal methods of music education can be integrated into the African music education curriculum.

The theoretical framework used to further understanding of the production and consumption of popular music in Africa uncovers the decision-making structures and processes in its production. This framework highlights the ability of African youths to generate new ideas for music production by combining traditional and modern lyrics. Interestingly, most popular musicians in 
Africa are Afrocentric, as their music is largely based on their understanding of the realities in Africa, including the experience of apartheid in South Africa, and political instability and underdevelopment in other African countries.

Additionally, the rate of consumption of popular music is higher than the rate of its production, indicating that the production process is complex and relatively difficult. In fact, some popular musicians have been unable to produce new music despite the enormous wealth they have amassed from their music and talents.

The central argument in this article suggests that, despite the problems they face, many young people have contributed significantly to the development of the African music industry. They have managed to do so by innovating and blending features from the traditional African system of music with select elements of foreign music, especially by adopting some popular music genres from Western Europe and North America.

This article also contributes by highlighting the role of ICT in the production and consumption of popular music by young Africans, many of whom use internet technology and social networking media to produce or consume popular music. Most African youths also take an interest in mobile phone and computer technologies, which they use to listen to popular music. This development points to the importance of technology-mediated production and consumption of popular music as evidence of the diffusion of innovation in the music industry across Africa.

Through the presentation of several cases of the way music is being produced and consumed across Africa, this article has established a cross-cultural conversation about young people's visibility and significance in this process. Policymakers and other youth development stakeholders should be aware that they can promote the involvement of young people in exploring entrepreneurial opportunities in the music industry as a catalyst for sustainable development in Africa. 


\section{References}

Abbink, G. J. (2005). Being young in Africa: The politics of despair and renewal. Retrieved from https://openaccess.leidenuniv.nl/handle/1887/9608

Agawu, K. (2003). Representing African music: Postcolonial notes, queries, positions. New York: Routledge.

AJzen, I. (1991). The theory of planned behavior. Organizational Behavior and Human Decision Processes, 50(2), 179-211.

- (2002). Perceived behavioral control, self-efficacy, locus of control, and the theory of planned behavior. Journal of Applied Social Psychology, $32,665-683$.

Ballantine, C. (1991). Music and emancipation: The social role of black jazz and vaudeville in South Africa between the 1920s and the early 1940s. Journal of South African Studies, 17(1), 129-152.

BARAK, B. (2009). Age identity: A cross-cultural global approach. International Journal of Behavioural Development, 33(1), 2-11.

BECKER, H. (1989). Ethnomusicology and sociology: A letter to Charles Seeger. Ethnomusicology, 33, 275-285.

Bennett, A. (2000). Popular music and youth culture: Music, identity and place. Basingstoke, UK: Macmillan Press Ltd.

BERry, J. (2011). Commentary: A world fit for youth. Ethos, 39(4), 452-454.

Bosch, T. E. (2014). Commercial music radio, racer and identity in South Africa. Media, Culture \& Society, 36(7), 901-915.

Boyd, D. (2007). Why youth (heart) social network sites: The role of networked publics in teenage social life. Cambridge, MA: The MIT Press.

Bucholtz, M. (2002). Youth and cultural practice. Annual Review of Anthropology, 31, 525-552.

Burrell, J. \& Anderson, K. (2008). I have great desires to look beyond my world': Trajectories of information and communication technology use among Ghanaians living abroad. New Media and Society, 10(2), 203-224.

Charry, E. (2000). Mande music: Traditional and modern music of the Maninka and Mandinka of Western Africa. Chicago: University of Chicago Press. 
Clarke, J., Hall, S, Jefferson, T., \& Roberts, B. (2003). Subcultures, cultures and class: A theoretical overview. In S. Hall \& T. Jefferson (eds.), Resistance through rituals: Youth subcultures in post-war Britain (pp. 9 - 74). New York: Routledge.

Cohen, J. E. (2003). Human population: The next half century. Science, 302(5648), 1172-1175.

Comacchio, C. R. (2006). The dominion of youth: Adolescence and the making of modern Canada, 1920-1950. Waterloo, Ontario, Canada: Wilfrid Laurier University Press.

DeJaeghere, J. \& BaXter, A. (2014). Entrepreneurship education for youth in sub-Saharan Africa: A capabilities approach as an alternative framework to neoliberalism's individualizing risks. Progress in Development Studies, 14(1), 61-76.

Dioneo-Adetayo, E. A. (2006). Factors influencing attitude of youth towards entrepreneurship. International Journal of Adolescence and Youth, 13(1-2), 127-145.

EHRLich, C. (1985). The music profession in Britain since the eighteenth century: A social history. Oxford: Clarendon Press.

Emielu, A. (2011). Some theoretical perspectives on African popular music. Popular Music, 30(3), 371-388.

Fleming, T. \& Falola, T. (2012) Introduction. In Toyin Falola and Tyler Fleming (eds.), Music, performance and African identities. (pp.1-34). New York: Routledge.

Frith, S. \& Horne, H. (1987). Art into pop. London: Methuen and Co Ltd.

Frith, S. (1996). Performing on the value of popular music rites. Cambridge, Massachusetts: Harvard University Press.

Giddens, A. (1984). The constitution of society: Outline of the theory of structuration. Berkeley: University of California Press.

Goldman, S., Booker, A. \& McDermott, M. (2008). Mixing the digital, social, and cultural: Learning, identity, and agency in youth participation. In David Buckingham (ed.), youth, identity, and digital media (pp. 15-206). Cambridge, MA: The мIт Press.

Green, L. (2016). How popular musicians learn: A way ahead for music education. New York: Routledge.

НАмм, C. (1995). Putting popular music in its place. Cambridge, uK: Cam- 
bridge University Press.

Koster, M. W. (2013). The hip hop revolution in Kenya: Ukoo Flani Mau Mau, youth politics and memory, 1990-2012. The Journal of Pan African Studies, 6(3), 82-105.

Kuratko, D. F., Morris, M. H. \& Covin, G. J. (2011). Corporate innovation and entrepreneurship, third edition. Stamford, US: South-Western Cengage Learning.

LANGLOIS, T. (1996). The local and the global in North African popular music. Popular Music, 15(3), 259-273.

Longhurst, B. (2007). Popular music and society, second edition. Cambridge, UK: The Polity Press.

Malebana, J. (2014). Entrepreneurial intentions of South African rural university students: A test of the theory of planned behavior. Journal of Economics and Behavioral Studies, 6(2), 130-143.

Martin, D. (2013). Sounding the cape: Music, identity and politics in South Africa. Somerset West, South Africa: African Minds.

MARTin, P. J. (2006). Musicians' worlds: Music-making as a collaborative activity. Symbolic Interaction, 29(1), 95-107.

MAssey, D. S. (2002). A brief history of human society: The origin and relevance of human emotion. American Sociological Review, 67(1), $1-29$.

Mercer, C. (2005). Telecentres and transformations: Modernizing Tanzania through the internet. African Affairs, 105(419), 243-264.

Messenger, J. (1958). Esthetic talent. Basic College Quarterly, 4, 20-24.

Miller, L. \& MAKeba, M. (2000). Miriam Makeba. BOMB, 72, 90-95.

NAbudere, D. (2011). Afrikology: Philosophy and Wholeness. Pretoria: Africa Institute of South Africa.

Nyamnjoh, F. B. \& Fokwang, J. (2005). Entertaining repression: Music and politics in postcolonial Cameroon. African Affairs, 104(415), 251274.

OGone, J. O. (2014). Framing the urban hustler: Space and identity discourse in Kenyan popular music. The Journal of Pan African Studies, 6(9), 179-200.

OKPAKU, J. (1986). Telecommunications technology in Africa. In J. O. Okpaku, A. E. Opubor \& B. O. Oloruntimehin (eds.), The arts and civilization of black and African people, volume ten (pp. 72-81). Lagos: CBAAC. 
OKuYade, O. (2011). African China, Nigerian popular music, national development and the search for musical idiom. Muziki, 8(1), 50-59.

OnYeJI, C. (2009). Social transformation in South Africa through the musical arts: A Batswana experience with specific reference to the Ikageng-Bill Cosby cultural group. Journal of the Musical Arts in Africa, 6(1), 35-58.

Porter, E. C. (2002). What is this thing called jazz? African American musicians as artists, critics, and activists. California: University of California Press.

Ramirez, J. M. (2005). Peace and development in Africa. International Journal on World Peace, 22(3), 51-73.

Rogers. E. M. (2010). Diffusion of innovation, fourth edition. New York: The Free Press.

Russell, D. (1997). Popular music in England, 1840-1914: A social history, second edition. Manchester: Manchester University Press.

Schumann, A. (2013). Songs of a new era: Popular music and political expression in the Ivorian crisis. African Affairs, 112(448), 440-459.

Sesay, A. (2014). African governance systems in pre and post-independence periods: Enduring lessons and opportunities for youth in Africa. Johannesburg: The Mandela Institute for Development Studies.

Suleiman, E. B. (2015). Entrepreneurship for development. Convocation lecture delivered at the second convocation ceremony in Kaduna State University. Kaduna, Nigeria: Kaduna State University.

TABAn, A. E. (2017). Youth unemployment and insecurity in the greater horn of Africa: A case study of Munuki Payam in South Sudan. Retrieved from http://erepo.usiu.ac.ke/handle/11732/3613

Thompson, J. B. (1995). The media and modernity: A social theory of the media. Stanford, California: Stanford University Press.

VALKonen, T. (1970). On the theory of diffusion of innovations. University of Helsinki Institute of Sociology, 76, 162-179.

W ANDA, R. E. (2013). Afrikology and community: Restorative cultural practices in east Africa. The Journal of Pan African Studies, 6(6), 1-25.

Weber, W. (2004). The musician as entrepreneur and opportunist, 17001914. In William Weber (ed.), The musician as entrepreneur, $1700-$ 1914: Managers, charlatans and idealists (pp. 3-24). Bloomington, USA: Indiana University Press.

Wulstan, D. (1985). Tudor music. Oxford: Oxford University Press. 